\title{
Absence of Obvious Short Term Impact of the Nematode-Trapping Fungus Duddingtonia Flagrans on Survival and Growth of the Earthworm Aporrectodea Longa
}

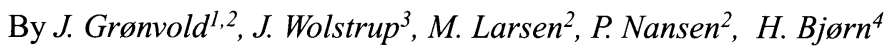

${ }^{1}$ Section of Zoology, Department of Ecology, ${ }^{2}$ Danish Center for Experimental Parasitology, Department of Veterinary Microbiology, ${ }^{3}$ Section of Microbiology, Department of Ecology, The Royal Veterinary and Agricultural University, ${ }^{4}$ Danish Veterinary Laboratory, Copenhagen, Denmark.

\begin{abstract}
Grønvold J, Wolstrup J, Larsen M, Nansen P, Bjørn H: Absence of obvious short term impact of the nematode-trapping fungus Duddingtonia flagrans on survival and growth of the earthworm Aporrectodea longa. Acta vet. scand. 2000, 41, 147151 - The nematode-trapping fungus Duddingtonia flagrans may be used in biological control of parasitic nematode larvae in faeces of domestic host animals after feeding the hosts with fungal chlamydospores. In this experiment a possible undesirable fungal impact on earthworms, of the species Aporrectodea longa, was investigated. As earthworms eat animal faeces, $D$. flagrans may come into contact with earthworms both in their alimentary tract and on their body surface. However during the experimental period of 20 days, when earthworms were living in soil and eating cattle faeces that were heavily infested with viable chlamydospores of $D$. flagrans there were no indications of internal or external mycosis among the earthworms.
\end{abstract}

earthworm; undesirable impact.

\section{Introduction}

Earthworms of the family Lumbricidae are common powerful soil animals in the temperate and colder regions of the Northern Hemisphere, where they consume large quantities of soil together with living or dead organic materials, e.g. animal excrements. In the earthworm gizzard soil particles participate in the crushing of living microorganisms (e.g. bacteria, fungi, protozoans and nematodes) present in soil, animal excrements (e.g. cow pats) or in plant remains. In doing so they also break down the organic materials into very fine particles. The importance of this action cannot be overestimated, as it speeds up the microbial mediated recycling of plant nutrients in earthworm excrements.
Experiments on biological control have shown that chlamydospores of the nematode-trapping soil fungus Duddingtonia flagrans fed to domestic animals survive gut passage and subsequently create a mycelium that attacks small parasitic nematode larvae developing in the faeces (e.g. in cow pats) (Grønvold et al. 1993, Wolstrup et al. 1994, Larsen et al. 1995 and 1996, Nansen et al. 1995 and 1996, Githigia et al. 1997). However, the presence of D. flagrans in large quantities in faeces, from where it can be spread to the surrounding pasture soil, may in theory be harmful to earthworms either externally or internally.

On the other hand, it is possible that earthworms are able to protect themselves against 
fungal attack to a certain extent, as it has been shown that earthworms may excrete antifungal substances through their body surface (van der Bruel 1964, Ghabbour 1966). It is also possible that some portion of $D$. flagrans chlamydospores are destroyed, when eaten by earthworms together with soil or faeces, but no doubt many fungal spores survive passage through the earthworm gut (Griffin 1972).

The possible impact of $D$. flagrans on the Danish earthworm Aporrectodea longa has been the subject of the present investigation.

\section{Materials and methods}

\section{Experimental set up}

The experiment was performed in 6 plastic buckets (diam.: $21 \mathrm{~cm}$; height: $18 \mathrm{~cm}$ ), each filled with $3 \mathrm{~kg}$ dark orchard soil (depth: $8 \mathrm{~cm}$ ). The soil had been sieved (mesh size of $1 \mathrm{~cm}$ ) and mixed. Soil $\mathrm{pH}$ was 6.7 , soil water content was $18 \%$ of wet weight and the organic content was $8 \%$ of soil dry weight.

Half of the soil surface, in each bucket, was covered with a portion of $300 \mathrm{~g}$ of cattle faeces. The faeces had been placed in open air in the laboratory for 2 weeks before the start of the experiment, to allow gases to evaporate, as it is well known that fresh faeces are toxic to earthworms. At the start of the experiment, the faeces had a water content of $84 \%$ of wet weight and the organic content was $85 \%$ of faecal dry weight. The $\mathrm{pH}$ in the faeces was not measured, but is normally between 7 and 8 .

Before placing the soil and faeces in the experimental buckets, chlamydospores of $D$. flagrans were mixed with both faeces and soil in 3 of the buckets (fungal buckets). The other 3 buckets (control buckets) were without D. flagrans chlamydospores.

Groups of 17 earthworms, of the species $A$. longa, with approximately the same size distribution and total weight, were subsequently placed in each bucket for an experimental pe- riod of 20 days. After that period, the earthworms were followed for another 10 days, after transferring them to ordinary orchard soil.

\section{The nematode-trapping fungus}

The nematode-trapping fungus Duddingtonia flagrans Cooke 1969 (strain: Trol A) was cultivated on millet seeds yielding a chlamydospore concentration of $9 \times 10^{6}$ chlamydospores $/ \mathrm{g}$ millet seed culture. The germination capacity, on corn meal agar, at the start of the experiment, was estimated to be not less than $10 \%$ and not more than $50 \%$, which is within the usual range on this food base. The mycelium formed by the germinating chlamydospores looked normal and was dense.

The concentrations of $D$. flagrans chlamydospores (CHL) mixed into cattle faeces and soil in the 'fungal buckets' were:

1) faeces: $240000 \mathrm{CHL} / \mathrm{g}$ ( $8 \mathrm{~g}$ millet seed culture in $300 \mathrm{~g}$ faeces).

2) soil: $75000 \mathrm{CHL} / \mathrm{g}$ (25 g millet seed culture in $3 \mathrm{~kg}$ soil).

Faeces and soil in 'control buckets' received the same amount (weight) of millet seeds, but without chlamydospores of D. flagrans.

\section{Earthworms}

Earthworms (Aporrectodea longa Ude 1885 (Lumbricidae)) were collected in the same orchard as the soil. The earthworms were adult or subadult (i.e. beginning to develop adult characteristics), each having an average fresh weight of approximately $2 \mathrm{~g}$ (their guts were not emptied before weighing).

Air temperature, humidity and watering of the experimental buckets

At the start of the experiment, the experimental buckets were placed in a climatic chamber, securing a constant temperature of $15^{\circ} \mathrm{C}$ and an air relative humidity of $98 \%$. During the 20 day experimental period all buckets were watered 
Table 1. Survival (no.) and weight gains or losses (growth) of the earthworm Aporrectodea longa living for 20 days in buckets containing a bottom layer of $3 \mathrm{~kg}$ orchard soil with $300 \mathrm{~g}$ cattle faces on top of it. Half of the buckets $(+)$ contained soil and faeces that had been heavily infested by chlamydospores of the nematode-trapping fungus Duddingtonia flagrans. The other half of the buckets (-) was not inoculated with D. flagrans.

\begin{tabular}{|c|c|c|c|c|c|c|}
\hline \multirow{2}{*}{$\begin{array}{l}\text { Bucket } \\
\text { no. }\end{array}$} & \multirow[b]{2}{*}{$+/$-fungus } & \multicolumn{2}{|c|}{$\begin{array}{c}\text { Day } 0 \\
\text { Earthworm }\end{array}$} & \multicolumn{2}{|c|}{$\begin{array}{c}\text { Day } 20 \\
\text { Earthworm }\end{array}$} & \multirow{2}{*}{$\begin{array}{c}\text { Total } \\
\text { growth }(\mathrm{g})\end{array}$} \\
\hline & & No. & weight (g) & No. & weight (g) & \\
\hline 1 & + & 17 & 34.8 & 17 & 42.1 & +7.3 \\
\hline 2 & + & 17 & 31.7 & 18 & $33.4(31.5)^{*}$ & $-0.2 * *$ \\
\hline 3 & + & 17 & 33.8 & 17 & 39.2 & +5.4 \\
\hline 4 & - & 17 & 32.0 & 17 & 31.3 & -0.7 \\
\hline 5 & - & 17 & 35.5 & 17 & 37.1 & +1.6 \\
\hline 6 & - & 17 & 36.6 & 17 & 36.1 & -0.5 \\
\hline
\end{tabular}

Corrections are marked by asterisks:

*) $(33.4-33.4 / 18)=31.5$; subtraction of the average weight of 1 earthworm.

**) $(31.5-31.7)=-0.2$; corrected total weight gain.

by the same amount of between 25 and $100 \mathrm{ml}$ tap water daily ( $625 \mathrm{ml}$ for the whole period).

This procedure resulted in a rise in the soil water content; starting at $18 \%$ (rather dry) and rising to $29 \%$ (soaked) at day 20 . It must be expected that this fluctuation in soil water content gave $D$. flagrans an optimal opportunity to germinate some time during the whole experimental period.

\section{Results}

The earthworms in the 'fungal buckets' undoubtedly had surface contact with living $D$. flagrans chlamydospores throughout the 20 day experimental period. Between $231 \mathrm{~g}$ and $267 \mathrm{~g}$ (more than $75 \%$ of the faeces) were eaten in each of all the buckets during the experiment; hence intestinal contact between earthworms and living chlamydospores most likely occurred.

However, as shown in Table 1, there was no reduction in numbers of earthworms (survival) and, statistically, there was no significant difference in growth (weight gains or losses; based on earthworms, which had not had their gut emptied) in the 2 groups during the 20 day experimental period $(0.2<\mathrm{p}<0.3$, using a Students $t$-test). Moreover, comparing the 2 groups of earthworms their general appearance was the same, i.e. they had the normal coelomic pressure, the normal colour, their gut was not empty (they had been eating) and their reflex movements were normal. The presence of one additional earthworm in bucket no. 2 , at the end of the experiment, cannot change this general conclusion. Notice that the total growth of the earthworms in bucket no. 2 has been corrected in Table 1, because of this additional animal.

\section{Discussion}

In the present experiment, earthworms in 'fungal buckets' were living in soil and eating cattle faeces that were heavily infested with viable chlamydospores of $D$. flagrans. Based on their general appearance, their numbers (survival) and their average body weight gains/losses (growth), at the end of the 20 day experimental period, nothing indicated that $D$. flagrans was harmful to $A$. longa when comparing 'fungal buckets' and 'control buckets'. Following the 
earthworms for another 10 days, after transferring them to ordinary orchard soil, did not change the above conclusion. They stayed healthy.

In a preliminary experiment, $4 \mathrm{~A}$. longa, living for 5 days in a mixture of $200 \mathrm{~g}$ of soil and 150 $\mathrm{g}$ of millet culture of $D$. flagrans, containing $1.2 \times 10^{6} \mathrm{CHL} / \mathrm{g}$ culture, and then observed for another 11 days, showed no signs of mycosis. Exposure to such a high fungal concentration supported the main result, that $D$. flagrans is harmless to earthworms, at least on a short term basis. For comparison, D. flagrans is able to penetrate the nematode cuticle and kill small nematodes in less than $24 \mathrm{~h}$. But of course freeliving larvae of parasitic nematodes are much smaller than adult or subadult earthworms, and a direct comparison is not meaningful. In addition the large powerful earthworms may clean their body surface by sliding through the soil. But also the constant secretion of mucus from the cuticle may clean them.

There was no indications of fungal attack by $D$. flagrans chlamydospores inside the earthworms either, as both group were eating comparable amounts of faeces and both groups stayed healthy. D. flagrans does not grow under anaerobic conditions (Grønvold et al. 1999), and the oxygen concentration that prevails in the alimentary tract of earthworms may be too low for the fungus to be active.

Based on the present laboratory experiment it must be expected, that the use of $D$. flagrans chlamydospores in faeces of domestic animals to control the development of parasitic nematode larvae, will be harmless to earthworms living in pasture soils.

However, it must be emphasized that the present conclusion only deals with acute, short term effects. Long term effects on survival, growth and reproduction are possibilities that need further investigations.

\section{Acknowledgements}

We want to thank Dr. Christian Sommer, The Royal Veterinary and Agricultural University, Frederiksberg, for valuable comments on the manuscript. Hanne Rawat is acknowledged for her competent technical assistance. Chr. Hansen's Bio Systems A/S supported this investigation.

\section{References}

Bruel WE van der: Le sol, la pedofauna et les application de pesticides. Annales de Gembloux. 1964, 70, 81-101.

Cooke RC: Two nematode-trapping Hyphomycetes, Duddingtonia flagrans gen. et comb.nov. and Monacrosporium mutabilis sp. nov. Transactions of the British Mycological Society. 1969, 53, 315-319.

Ghabbour SI: Earthworms in agriculture: a modern evaluation. Rev. Ecol. Biol. Soc. 1966, 111, 258271.

Githigia SM, Thamsborg SM, Larsen M, Kyvsgaard $N C$, Nansen $P$ : The preventive effect of the fungus Duddingtonia flagrans on trichostrongyle infections of lambs on pasture. Int. J. for Parasit. 1997, 27, 931-939.

Griffin DM: Ecology of soil fungi. Syracuse University Press. 1972, 193 pp.

Grønvold J, Wolstrup J, Larsen M, Henriksen SA, Nansen P: Biological control of Ostertagia ostertagi by feeding selected nematode-trapping fungi to calves. J. Helminth. 1993, 67, 31-36.

Grønvold J, Wolstrup J, Nansen P, Larsen M, Henriksen $S A$, Bjørn H, Kirchheiner $K$, Lassen K, Rawat $H$, Kristiansen $H L$ : Biotic and abiotic factors influencing growth rate and production of traps by the nematode-killing fungus Duddingtonia flagrans when induced by Cooperia oncophora larvae. J. Helminth. 1999, 73, 129-136.

Larsen M, Nansen P, Wolstrup J, Grønvold J, Henrik$\operatorname{sen} S A$, Zorn A: Biological control of trichostrongyles in calves by the fungus Duddingtonia $\mathrm{fla}$ grans fed to animals under natural grazing conditions. Vet. Parasitol. 1995, 60, 321-330.

Larsen M, Nansen P, Grøndahl C, Thamsborg SM, Grønvold J, Wolstrup J, Henriksen SA, Monrad J: The capacity of the fungus Duddingtonia flagrans to prevent strongyle infections in foals on pasture. Parasitol. 1996, 113, 1-6.

Nansen P, Larsen M, Grønvold J, Wolstrup J, Zorn A, Henriksen SA: Prevention of clinical trichostrongylidosis in calves by strategic feeding with the 
predacious fungus Duddingtonia flagrans. Parasitol. Research. 1995, 81, 371-374.

Nansen P, Larsen M, Roepstorff A, Grønvold J, Wolstrup J, Henriksen SA: Control of Oesophagostomum dentatum and Hyostrongylus rubidus in outdoor-reared pigs through daily feeding with the microfungus Duddingtonia flagrans. Parasitol. Research. 1996, 82, 580-584.

Wolstrup J, Grønvold J, Henriksen SA, Nansen P, Larsen $M$, Bøgh $H O$, Ilsøe $B$ : An attempt to implement the nematode-trapping fungus Duddingtonia flagrans in biological control of trichostrongyle infections of first year grazing calves. J. Helminth. 1994, 68, 175-180.

\begin{abstract}
Sammendrag
Mulig korttidsvirkning af den nematod-fangende svamp Duddingtonia flagrans på overlevelse og veekst af regnormen Aporectodea longa.

Den nematod-fangende svamp Duddingtonia flagrans har vist sig at være anvendelig til biologisk bekæmpelse af parasitiske nematod-larver i husdyrgødning efter fodring af værtsdyrene med svampens chlamydosporer. Denne undersøgelse omhandler en mulig uønsket svampe-effekt på regnormen Aporrectodea longa. Da regnorme spiser dyriske ekskrementer, er det muligt at $D$. flagrans kan komme i kontakt med regnorme både i deres tarmkanal og på deres kropsoverflade. I den her anvendte forsøgsperiode på 20 dage, hvor regnorme levede $\mathrm{i}$ jord og spiste kogødning, der var kraftigt inficeret med levende chlamydosporer af $D$. flagrans, men også efterfølgende, var der ingen indikationer på intern eller ekstern mykose blandt regnormene.
\end{abstract}

(Received December 7, 1999; accepted February 4, 2000).

Reprints may be obtained from: J. Grønvold, Section of Zoology, Department of Ecology, The Royal Veterinary and Agricultural University, Bülowsvej 13, DK-1870 Frederiksberg C, Denmark. E-mail: jrg@kvl.dk, tel: +45 35282676 , fax: +4535282676. 